\title{
Impact of land use/land cover changes on ecosystem services in the Nenjiang River Basin, Northeast China
}

\author{
Zhiliang Wang ${ }^{1,2,3^{*}}$, Zongming Wang ${ }^{1}$, Bai Zhang ${ }^{1}$, Chunyan Lu ${ }^{1,2}$ and Chunying Ren ${ }^{1}$
}

\begin{abstract}
Introduction: The Nenjiang River Basin is an important foodstuff base and eco-environmental fragile area in Northeast China. With the rapid rise in human population, human-induced changes in land use/land cover form an important component of regional environment and ecosystem service change. At the local and regional level, the ecosystem service concept can act as a decision support tool for a stakeholder to reach sustainable land use management. However, the prevailing ecosystem service evaluation would produce a biggish warp when it is applied to concrete area. So, it is essential to evaluate ecosystem service change according to the local actuality.
\end{abstract}

Method: According to 1:250,000 land use/land cover maps of China and the adjusted equivalent value per unit area of ecosystem services in the Nenjiang River Basin, we evaluated the ecosystem service change of the river basin from 1980 to 2005.

Results: The forest and wetland, which are mainly located in the upstream mountainous area of the Nenjiang River Basin, were the two valuable land cover types, accounting for more than three quarters of the total ecosystem service value of the river basin. As for individual ecosystem service, besides the food production, all of the ecosystem service values declined from 1980 to 2005. The total decline of 2.43 billion USD was mainly due to the cultivation of grassland (14.34 \% of the area in 1980) and wetland (4.62\% of the area in 1980) in the downstream plain.

Conclusions: Due to the increase in population and the concomitant requirement of grain, the inconsistency between decision-making at the macro-level, and the objective of agricultural production at the micro-level, cultivated land was increased through zealous reclamation of grassland, marginal woodland, and even fallow land. Tremendous land use/land cover changes had caused great damages to the ecological environment such as land degradation and ecosystem service recession. So, the policies of the Grain for Green and Construction of Ecological Province projects should be well-implemented to optimize land use/land cover.

Keywords: Land use/land cover changes; Ecosystem services; Equivalent value; NDVl; Nenjiang River Basin

\section{Introduction}

The Nenjiang River, previously be called the Nonni River at the beginning of the Qing Dynasty, means "The Green River" in Mongolian. The river basin used to be the haven of water birds for the wild spreading wetland which was bred by tens of rivers from the Da and Xiao Xing'anling Ranges. But after a hundred years of cultivation, there emerged thousands of large-scale farms

\footnotetext{
* Correspondence: jodver@163.com

${ }^{1}$ Northeast institute of Geography and Agroecology, Chinese Academy of Sciences, Changchun 130102, China

2University of Chinese Academy of Sciences, Beijing 100101, China Full list of author information is available at the end of the article
}

accommodating $15.9 \times 10^{6}$ population (Dong, 2013). Especially after the reform era of the late 1970s, the old collective production brigade farming system was abandoned in favor of the household responsibility system to unleash farmers' incentives for higher productivity and more income (Liu et al. 2004). Large-scale state farms had been established as an important "grain base" through zealous reclamation of grassland, marginal woodland, and wetland. With the rapid rise in human population, human-induced changes in land use/land cover form an important component of regional environment and ecosystem service change. Whereas, at the 
local and regional level, the ecosystem service concept can act as a decision support tool for a stakeholder to reach sustainable land use management (Anna and Sabine 2011). The ecosystem service value assessment should be carried out as soon as possible. In China, the ecosystem service values of large-scale basins all have been evaluated (Liu et al. 2006; Wu et al. 2009; Hou et al. 2013; Bai et al. 2011; Liu et al. 2014). So, it is necessary to evaluate the ecosystem service change of the Nenjiang River Basin to constitute accurate policy for sustaining development. In this study, on the basis of land use/land cover changes and the achievements of other researchers from 1980 to 2005, the ecosystem service value of the Nenjiang River Basin was evaluated through the equivalent value per unit area of Chinese terrestrial ecosystem and the normalized difference

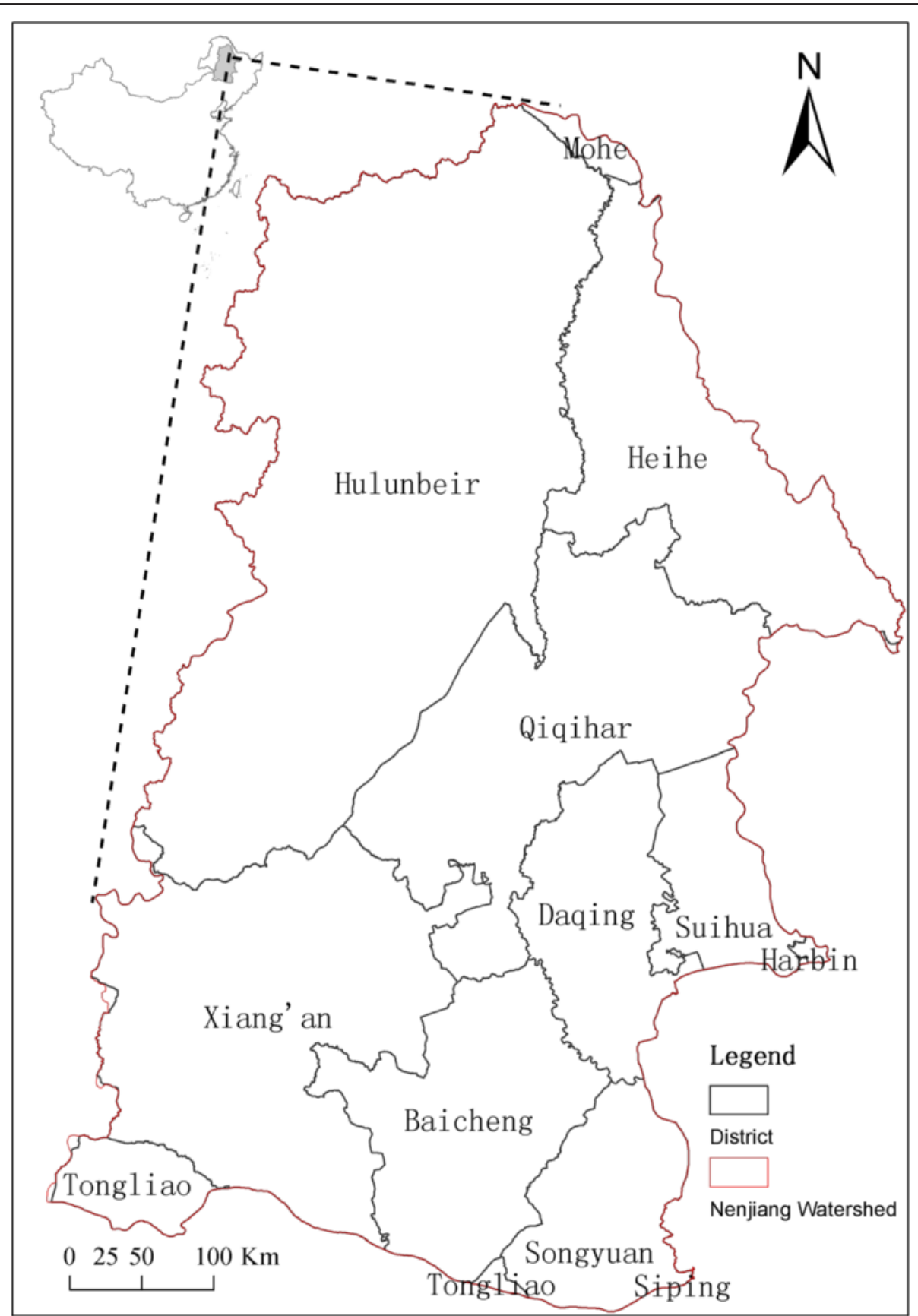

Fig. 1 Location of the Nenjiang River Basin 
vegetation index (NDVI). Especially, we hope to achieve three objectives: (1) to reveal the dynamics of land use/ land cover changes in the Nenjiang River Basin and its driving forces, (2) to evaluate the ecosystem service change of the river basin from 1980 to 2005, and (3) to map the ecosystem services of the Nenjiang River Basin.

\section{Methods}

\section{Study area}

The Nenjiang River Basin is located in the midwest of Heilongjiang Province, Northeast China. The Nenjiang River, which originates from the Yilehuli mountain of the Da Xing'anling Ranges, is the northern source of the Songhua River (Sun and Bai 2005). The length of the river is $1370 \mathrm{~km}$ with a catchment area of $29.4 \times 10^{4}$ $\mathrm{km}^{2}$, accounting for $53.8 \%$ of the total Songhua River Basin (total area is $54.6 \times 10^{4} \mathrm{~km}^{2}$ ).

The basin (Fig. 1) lies on the northern margin of the East Asian monsoon region and has a cold and semihumid continental monsoon climate with long, cold winters and short, rainy summers. The average annual temperature ranges from -4 to $6{ }^{\circ} \mathrm{C}$. Rivers are frozen from late October to early November and melt in early April (Li et al. 2014). However, spatial and temporal differences in rainfall and temperature vary greatly throughout the basin for its unique geographical position, shape, and terrain features.

\section{Data}

The basic data used in this study include (1) 1:250,000 land use/land cover maps of China in 1980 and 2005, which were obtained from data sharing infrastructure of Earth System Science (http://www.geodata.cn/). There are 6 level I categories and 25 level II categories of land use/land cover types. In our study, in order to calculate ecosystem service value for each land cover type identified in Xie et al.'s (2003) ecosystem service valuation model, six level I categories were reclassified as forest, grassland, farmland, wetland, lakes/rivers, and barren land. Wetland and water body was divided into two categories, and residential land and desert were united as barren land; (2) equivalent value per unit area of ecosystem services for terrestrial ecosystem in China (Xie et al. 2003); (3) $1-\mathrm{km}^{2}$ resolution of NOAA/AVHRR NDVI index around China in 1998, which was obtained from the Thematic Database for Human-Earth System (http:// www.data.ac.cn).

\section{Revising the equivalent value per unit area of Chinese terrestrial ecosystem}

For evaluating the global ecosystem value, Costanza et al. (1997) defined the theory and methodology of ecosystem service evaluation clearly from scientific purport. However, it was controversial in China, with some ecosystem services poorly valued or ignored (Zhang et al. 2013). When it was applied to concrete area, the methods would produce biggish warp due to (1) the value of ecosystem services reflected the economic level of developed countries such as the United States and European countries, rather than developing countries such as China; (2) although wetland ecosystems provide significant functions, their value per unit area was overvalued (Zhang et al. 2013). So, to adjust Costanza et al.'s (1997) value coefficients, Xie et al. (2003) constituted the equivalent value per unit area of ecosystem services for Chinese terrestrial ecosystem based on questionnaire investigation from about 200 ecological scholars and some achievements (Table 1).

The equivalent value per unit area of ecosystem services is the latent ability of the ecosystem services

Table 1 Equivalent value per unit area of ecosystem services for terrestrial ecosystem in China

\begin{tabular}{|c|c|c|c|c|c|c|}
\hline Item & Forest & Grassland & Farmland & Wetland & Lakes/rivers & Barren \\
\hline Gas regulation & 3.50 & 0.80 & 0.50 & 1.80 & 0 & 0 \\
\hline Climate stability $^{a}$ & 2.70 & 0.90 & 0.89 & 17.10 & 0.46 & 0 \\
\hline Water regulation and supply & 3.20 & 0.80 & 0.60 & 15.50 & 20.38 & 0.03 \\
\hline Soil generation and fertility ${ }^{\mathrm{b}}$ & 3.90 & 1.95 & 1.46 & 1.71 & 0.01 & 0.02 \\
\hline Waste treatment & 1.31 & 1.31 & 1.64 & 18.18 & 18.18 & 0.01 \\
\hline Biodiversity protection $^{c}$ & 3.26 & 1.09 & 0.71 & 2.50 & 2.49 & 0.34 \\
\hline Food production & 0.10 & 0.30 & 1.00 & 0.30 & 0.10 & 0.01 \\
\hline Raw materials & 2.60 & 0.05 & 0.10 & 0.07 & 0.01 & 0 \\
\hline Recreation, cultural & 1.28 & 0.04 & 0.01 & 5.55 & 4.34 & 0.01 \\
\hline Sum & 21.85 & 7.24 & 6.91 & 62.71 & 45.97 & 0.42 \\
\hline
\end{tabular}

${ }^{a}$ Climate stability includes climate regulation and disturbance regulation

${ }^{b}$ Soil generation and fertility includes soil formation, nutrient cycling, erosion control, and sediment retention

'Biodiversity protection includes pollination, biological control, refuge, and genetic resources mentioned by Costanza et al. (1997) 
produced by unit area of ecosystem. One equivalent value was defined as the economic value produced by 1ha farmland in China. Thus, Table 1 could be transformed into a table of economic value of ecosystem services for the same year. However, it just provides an average equivalent value per unit area of ecosystem services in China. Proverbially, there exist affinities between ecosystem service value and biomass. The bigger the biomass, the higher the ecosystem service value it has. In addition, NDVI could be used as an indicator of relative biomass and greenness (Boone and Galvin 2000; Freitas and Mello 2005; Loris and Damiano 2006; Zhang et al. 2007). Various authors have related this index to vegetation structures, such as vegetation cover, biomass, and leaf area index, as well as some functional characteristics, such as primary production and carbon balance

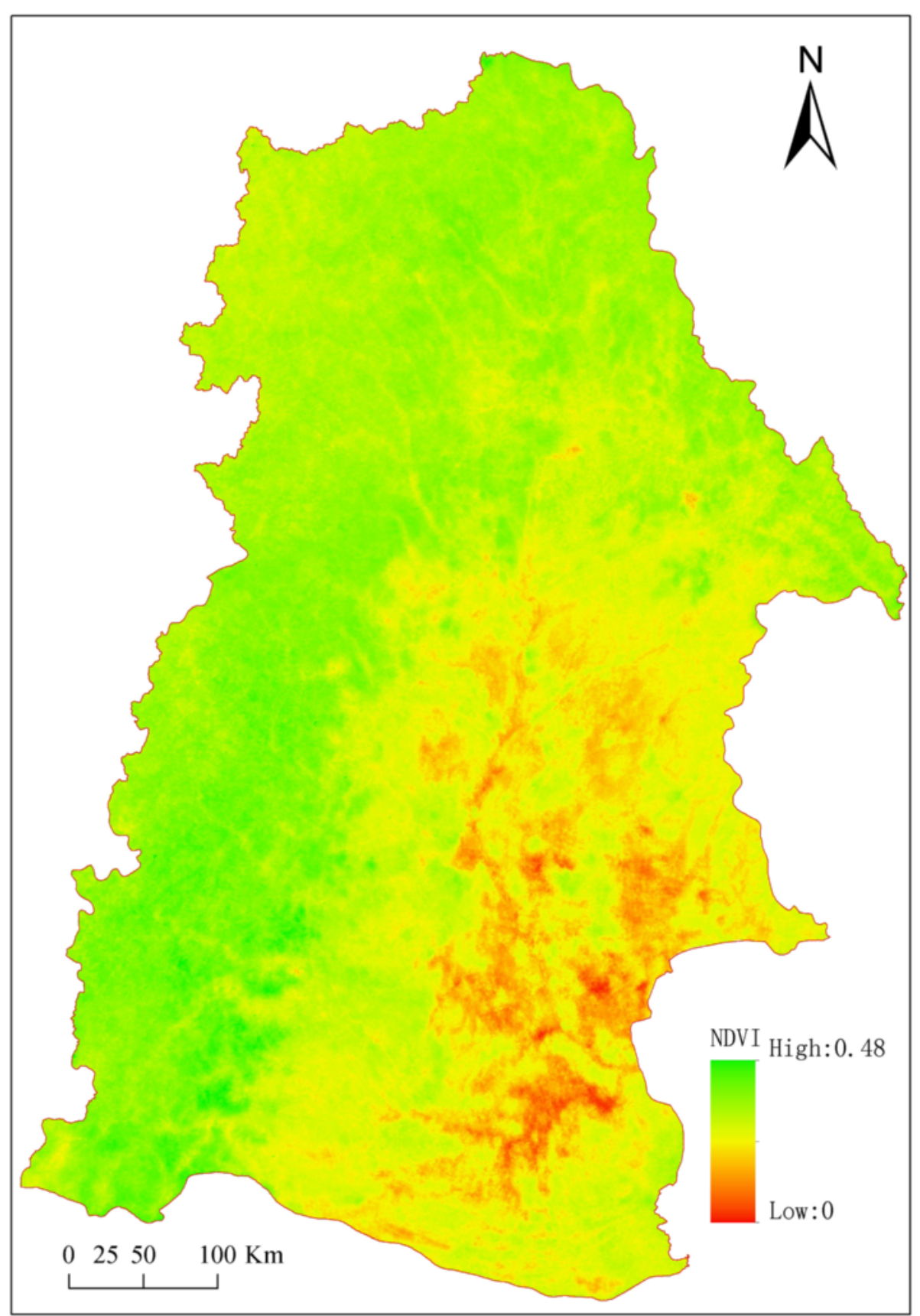

Fig. 2 Average NDVI of the Nenjiang River Basin in 1998 
Table 2 The average NDVI of China and the Nenjiang River Basin

\begin{tabular}{lll}
\hline Month & China & Nenjiang River Basin \\
\hline Jan. & 0.014 & 0.031 \\
Feb. & 0.015 & 0.031 \\
March & 0.017 & 0.081 \\
April & 0.022 & 0.066 \\
May & 0.039 & 0.233 \\
Jun. & 0.052 & 0.205 \\
Jul. & 0.059 & 0.343 \\
Aug. & 0.059 & 0.310 \\
Sep. & 0.054 & 0.316 \\
Oct. & 0.032 & 0.205 \\
Nov. & 0.023 & 0.029 \\
Dec. & 0.016 & 0.019 \\
\hline
\end{tabular}

(Running et al. 1999; Stoms and Hargrove, 2000; Huete et al. 2002; Kerr and Ostrovsky, 2003), some of which are important features in ecosystem service analysis (Roces-Díaz et al. 2014). So, we could assume a linear relationship between ecosystem service value and NDVI, then, revise the equivalent value per unit area of ecosystem services in the Nenjiang River Basin as follows:

$$
E i j=\frac{\mathrm{NDVI} m}{\mathrm{NDVI} n} \times e i j
$$

Where $E i j$ is the equivalent value per unit area of $i$ ecosystem service for $j$ ecosystem type after revisal; NDVIm is the average NDVI value of the Nenjiang River Basin (Fig. 2, Table 2), and NDVIn is the average NDVI value of China (Zhang et al. 2007); eij the equivalent value before revisal; $i=1,2,3, \cdots 9$, separately denote the ecosystem services; and $j=1,2,3, \cdots 6$, separately denote the land use types.

\section{Evaluating the ecosystem service value}

Through contrast analysis by Xie et al. (2003), one equivalent value per unit area equals one seventh of the average foodstuff market value in China. We could calculate the ecosystem service value of one equivalent value per unit area of ecosystem as follows:

$$
C=1 / 7 \sum_{i=1}^{n} \frac{V}{M}
$$

Where $C$ is the economic value of one equivalent value per unit area of ecosystem services, $V$ is the economic value of its crop produced by every farm, $M$ the area of its crop, and $n$ the categories of crop.

For lack of data, we took Hu et al.'s (2006) research as reference, of which the Chinese average economic value per unit area of farmland in 2005 was 3629.43 yuan $\cdot$ ha $^{-1}$; subtracting the unit area investment (930.33 yuan $\cdot \mathrm{ha}^{-1}$, including labors, fertilizer, mechanics, and others) and the rent shadow price $\left(2250\right.$ yuan $\left.\cdot \mathrm{ha}^{-1}\right)$, one equivalent value per unit area of ecosystems in China equaled to 449.10 yuan $\cdot \mathrm{ha}^{-1}$ (58.5 USD $\cdot \mathrm{ha}^{-1}$ ) (Xie et al. 2008). Presuming a linear relationship between ecosystem service value and biomass, the biomass factor of China was 1 , while the biomass factor of Heilongjiang province was 0.66 (Xie et al. 2005). So, we could set one equivalent value per unit area in the Nenjiang River Basin to 296.41 yuan $\cdot \mathrm{ha}^{-1}\left(38.61 \mathrm{USD} \cdot \mathrm{ha}^{-1}\right)$ in 2005.

By all accounts, we could calculate the total economic value in the Nenjiang River Basin by the following equation:

$$
\mathrm{ESV}=\sum_{i=1}^{9} \sum_{j=1}^{6} A j E i j C
$$

Where ESV is the total value of ecosystem services, and $A j$ is the area of $j$ ecosystem type in the Nenjiang River Basin.

\section{Ecosystem service sensitivity analysis}

Because there are uncertainties about the equivalent value per unit area of each ecosystem service for each ecosystem as well as the veracity of Costanza et al.'s (1997) value coefficients, we conducted sensitivity analysis to examine the dependence of our ecosystem service value estimation on the applied equivalent value

Table 3 Total area and area change of land use/cover from 1980 to $2005\left(10^{4} \mathrm{~km}^{2}\right)$

\begin{tabular}{lllllllllll}
\hline Land use & 1980 & Percent & Rank & 2005 & Percent & Rank & Change & Percent & Rank & Trend \\
\hline Forest & 10.20 & 34.66 & 1 & 9.87 & 33.54 & 2 & -0.33 & -3.24 & 5 & $\downarrow$ \\
Farmland & 9.09 & 30.88 & 2 & 10.11 & 34.39 & 1 & 1.02 & 13.46 & 1 & $\uparrow$ \\
Grassland & 4.78 & 16.24 & 3 & 4.13 & 14.06 & 3 & -0.65 & -11.32 & 2 \\
Wetland & 3.39 & 11.51 & 4 & 3.28 & 11.17 & 4 & -0.11 & -3.11 & 6 & $\downarrow$ \\
Barren land & 1.47 & 4.98 & 5 & 1.56 & 5.32 & 5 & 0.09 & 9.52 & 3 \\
Lakes/rivers & 0.51 & 1.73 & 6 & 0.46 & 1.52 & 6 & -0.05 & -6.72 & 4 \\
Sum & 29.42 & 100 & & 29.42 & 100 & & & & $\downarrow$ &
\end{tabular}


Table 4 Transition matrix of land use types from 1980 to 2005 (transition probabilities in \%)

\begin{tabular}{|c|c|c|c|c|c|c|c|}
\hline \multirow{2}{*}{$\begin{array}{l}\text { Land use } \\
\text { type in } 1980\end{array}$} & \multicolumn{7}{|c|}{ Land use type in 2005} \\
\hline & Grassland & Farmland & Barren & Forest & Wetland & Lakes/rivers & Sum \\
\hline Grassland & 80.96 & 14.34 & 1.41 & 2.00 & 1.20 & 0.10 & 19.05 \\
\hline Farmland & 0.26 & 98.80 & 0.12 & 0.59 & 0.19 & 0.04 & 1.20 \\
\hline Barren land & 0.04 & 0.15 & 99.72 & 0.02 & 0.02 & 0.05 & 0.28 \\
\hline Forest & 1.93 & 2.75 & 0.01 & 95.26 & 0.04 & 0.01 & 4.74 \\
\hline Wetland & 1.06 & 4.62 & 0.69 & 0.08 & 93.39 & 0.16 & 6.61 \\
\hline Lakes/rivers & 2.24 & 2.52 & 0.06 & 0.03 & 7.72 & 87.43 & 12.57 \\
\hline
\end{tabular}

per unit area of ecosystem services. The equivalent value for each ecosystem was adjusted by $50 \%$ (Wang et al. 2006). The coefficient of sensitivity (CS) was calculated as:

$$
\mathrm{CS}=\left|\frac{(\mathrm{ESV} j-\mathrm{ESV} i) / \mathrm{ESV} i}{(E j-E i) / E i}\right|
$$

Where ESV is the estimated value of ecosystem services, $E$ the equivalent value per unit area of ecosystem services, and $i$ and $j$ represent the initial and revisal value, respectively. CS $>1$ indicates that ecosystem service value estimation is elastic to the equivalent value, while $C S<1$ means inelastic to the equivalent value and accuracy of the equivalent value.

\section{Results}

\section{Land use/land cover changes}

As shown in Table 3, the two largest land use types were forest $\left(10.20 \times 10^{4} \mathrm{~km}^{2}\right.$, about $34.66 \%$ of total area in $1980 ; 9.87 \times 10^{4} \mathrm{~km}^{2}$, about $33.54 \%$ in 2005) and farmland $\left(9.09 \times 10^{4} \mathrm{~km}^{2}\right.$, about $30.88 \%$ of total area in $1980 ; 10.11 \times 10^{4} \mathrm{~km}^{2}$, about $34.39 \%$ in 2005) in this region.
From 1980 to 2005, the most notable changes of land use/land cover were an increment in farmland and a decline in grassland. In 1980, grassland covered $4.78 \times$ $10^{4} \mathrm{~km}^{2}$, about $16.24 \%$ of the total area; it decreased $11.32 \%$, about $6430 \mathrm{~km}^{2}$, which is about $257 \mathrm{~km}^{2}$ per year by 2005 . The area of lakes/rivers, forest, and wetland all decreased from 1980 to 2005 . Meanwhile, farmland increased $13.46 \%$, about $1.02 \times 10^{4} \mathrm{~km}^{2}$, which is about $411 \mathrm{~km}^{2}$ per year. Barren land also increased $985 \mathrm{~km}^{2}$, which is about $39 \mathrm{~km}^{2}$ per year.

Results of the transition matrix in Table 4 indicated the area increment or decline of each land use type. It was clear that between 1980 and 2005, the transition replacement rates of grassland and lakes/rivers were higher at 19.05 and $12.57 \%$, respectively. About $14.34 \%$ of grassland and $4.62 \%$ of wetland in 1980 were transformed to farmland; $7.72 \%$ of lakes/rivers was changed to wetland, because of 5 years of continuing drought after the big flood of the Nenjiang River in 1998 (Dong, 2013).

\section{Changes in ecosystem services}

According to Table 1 and Eq. (1), we calculated the equivalent value per unit area of ecosystem services in

Table 5 Equivalent value per unit area of ecosystem services in the Nenjiang River Basin

\begin{tabular}{|c|c|c|c|c|c|c|}
\hline Item & Forest & Grassland & Farmland & Marsh & Water & Barren \\
\hline Gas regulation & 16.28 & 3.72 & 2.33 & 8.37 & 0.00 & 0.00 \\
\hline Climate stability & 12.56 & 4.19 & 4.14 & 79.52 & 2.14 & 0.00 \\
\hline Water regulation and supply & 14.88 & 3.72 & 2.79 & 72.08 & 94.77 & 0.14 \\
\hline Soil generation and fertility & 18.14 & 9.07 & 6.79 & 7.95 & 0.05 & 0.09 \\
\hline Waste treatment & 6.09 & 6.09 & 7.63 & 84.54 & 84.54 & 0.05 \\
\hline Biodiversity protection & 15.16 & 5.07 & 3.30 & 11.63 & 11.58 & 1.58 \\
\hline Food production & 0.47 & 1.40 & 4.65 & 1.40 & 0.47 & 0.05 \\
\hline Raw materials & 12.09 & 0.23 & 0.47 & 0.33 & 0.05 & 0.00 \\
\hline Recreation, cultural & 5.95 & 0.19 & 0.05 & 25.81 & 20.18 & 0.05 \\
\hline Sum & 101.60 & 33.67 & 32.13 & 291.60 & 213.76 & 1.95 \\
\hline
\end{tabular}


Table 6 Total economic value of each ecosystem from 1980 to 2005 (billon USD)

\begin{tabular}{lllllllllll}
\hline & 1980 & Percent & Rank & 2005 & Percent & Rank & Change & Percent & Rank & Trend \\
\hline Forest & 40.00 & 40.03 & 1 & 38.71 & 39.70 & 1 & -1.29 & -3.24 & 5 & $\downarrow$ \\
Wetland & 38.14 & 38.16 & 2 & 36.95 & 37.90 & 2 & -1.18 & -3.11 & 6 & $\downarrow$ \\
Farmland & 11.27 & 11.28 & 3 & 12.55 & 12.87 & 3 & 1.28 & 11.32 & 2 \\
Grassland & 6.21 & 6.21 & 4 & 5.37 & 5.51 & 4 & -0.84 & -13.46 & 1 & $\downarrow$ \\
Lakes/rivers & 4.21 & 4.21 & 5 & 3.81 & 3.91 & 5 & -0.40 & -9.52 & 3 \\
Barren land & 0.11 & 0.11 & 6 & 0.12 & 0.12 & 6 & 0.01 & 6.72 & 4 \\
Sum & 99.94 & 100.00 & & 97.51 & 100.00 & & -2.43 & -2.43 & $\downarrow$ \\
\hline
\end{tabular}

the Nenjiang River Basin, and the results were listed in Table 5.

Based on Eq. (3), we calculated the changes of ecosystem service value in 1980 and 2005 (Table 6). From Table 6, the two valuable land use types were forest (40.00 billion USD, about $40.03 \%$ of the total value in 1980; 38.71 billion USD, about $39.70 \%$ of the total value in 2005) and wetland (38.14 billion USD, about $38.16 \%$ of the total value in 1980; 37.90 billion USD, about $37.90 \%$ of the total value in 2005) in this region, accounting for more than three quarters of the total basin ecosystem service value.

Although the area of farmland ranked the second and wetland ranked the fourth in Table 3, the total ecosystem value of farmland ranked below wetland's, obviously, because of its lower equivalent value per unit area. During the past 25 years, the total economic value of grassland decreased the most, about $13.46 \%$ of the total value in 1980, as well as lakes/rivers, forest, and wetland. Meanwhile, the total economic value of farmland and barren land increased 11.30 and $5.88 \%$, respectively, because of their increasing total area.

On the whole, the land use/land cover changes in the Nenjiang River Basin had led to a total net decline of 2.43 billion USD, about 97.2 million USD per year in ecosystem service value from 1980 to 2005 .
We also calculated the effects of land use/land cover changes to individual ecosystem services during the past 25 years (Table 7). Except for the economic value of food production, all kinds of ecosystem service values declined from 1980 to 2005. The most notable value decline was water regulation and supply service, about 0.64 billion USD; the next were waste treatment service and climate stability, because the warming and drying trend of the basin has influenced seasonal streamflow and altered the annual hydrograph of the basin; the decrease of streamflow in the lower basin (mainly alluvial plains) has caused wetland degradation, desertification, and soil salinization (Zhang and Guo 2008; Du et al. 2009).

\section{Ecosystem service sensitivity analysis}

When the equivalent value for each ecosystem was adjusted by $50 \%$, respectively, changes of total values in the Nenjiang River Basin and coefficient of sensitivity (CS) for each land use type were calculated (Table 8).

As shown in Table 8, the $50 \%$ adjustment to equivalent value of forest had the most impact on the total estimated ecosystem service value, the total value changed \pm 20.00 billion USD $\cdot \mathrm{a}^{-1}$ and \pm 19.07 billion USD . $\mathrm{a}^{-1}$ on the initial result of 1980 and 2005 respectively,

Table 7 Total economic value of each ecosystem service from 1980 to 2005 (billion USD)

\begin{tabular}{llllllllll}
\hline & 1980 & Percent & Rank & 2005 & Percent & Rank & Change & Rank & Trend \\
\hline Waste treatment & 18.92 & 18.93 & 1 & 18.49 & 18.97 & 1 & -0.43 & 2 & $\downarrow$ \\
Water regulation and supply & 18.83 & 18.84 & 2 & 18.18 & 18.65 & 2 & -0.64 & 1 & $\downarrow$ \\
Climate stability & 17.61 & 17.62 & 3 & 17.18 & 17.62 & 3 & -0.43 & 3 \\
Soil generation and fertility & 12.24 & 12.25 & 4 & 12.02 & 12.33 & 4 & -0.22 & 7 & $\downarrow$ \\
Biodiversity protection & 9.90 & 9.91 & 5 & 9.65 & 9.90 & 5 & -0.25 & 4 & $\downarrow$ \\
Gas regulation & 9.00 & 9.01 & 6 & 8.76 & 8.99 & 6 & -0.24 & 5 & $\downarrow$ \\
Recreation, cultural & 6.17 & 6.17 & 7 & 5.95 & 6.10 & 7 & -0.22 & 6 & $\downarrow$ \\
Raw materials & 5.01 & 5.01 & 8 & 4.87 & 4.99 & 8 & -0.14 & 8 & $\downarrow$ \\
Food production & 2.27 & 2.27 & 9 & 2.40 & 2.46 & 9 & 0.14 & 9 \\
Sum & 99.94 & 100 & & 97.51 & 100 & & -2.43 & $\uparrow$ \\
\hline
\end{tabular}


Table 8 The magnitude of changes in total economic values and CS (billion USD $\cdot \mathrm{a}^{-1}$ )

\begin{tabular}{llllll}
\hline Change of equivalent value & & \multicolumn{2}{l}{ Change of total values } & & CS \\
\cline { 3 - 4 } & & 1980 & 2005 & 1980 & 0.4003 \\
\hline Forest & $E \pm 50 \%$ & $119.94 \sim 79.94$ & $116.86 \sim 78.16$ & 0.0621 & 0.3970 \\
Grassland & $E \pm 50 \%$ & $103.04 \sim 96.84$ & $100.20 \sim 94.82$ & 0.1128 & 0.0551 \\
Farmland & $E \pm 50 \%$ & $105.58 \sim 94.30$ & $103.78 \sim 91.24$ & 0.3816 & 0.1287 \\
Wetland & $E \pm 50 \%$ & $119.01 \sim 80.87$ & $115.99 \sim 79.03$ & 0.0421 & 0.3790 \\
Lakes/rivers & $E \pm 50 \%$ & $102.05 \sim 97.83$ & $99.42 \sim 95.60$ & 0.0011 & 0.0391 \\
Barren land & $E \pm 50 \%$ & $100.00 \sim 99.88$ & $97.57 \sim 97.45$ & & 0.0012 \\
\hline
\end{tabular}

while the CS fluctuated between 0.4003 and 0.3970, correspondingly; the next was wetland. Adjustment to farmland, grassland, lakes/rivers, and barren land had little impact and the CS ranged from 0.0011 to 0.1287 .

Overall, the CS of these analyses were less than 1 under all scenarios, which indicated that the total ecosystem service value of study area were relatively inelastic with respect to the given equivalent value per unit area of ecosystem services in the Nenjiang River Basin. The equivalent value and ecosystem service evaluation in this study were acceptable.

\section{Ecosystem service space distribution}

In order to show the space distribution of ecosystem services in the Nenjiang River Basin, the maps of ecosystem services in 1980 (Fig. 3) and 2005 (Fig. 4) were drawn, and the average ecosystem service value of each city was calculated in Table 9.

From Figs. 3 and 4 and Table 9, we could get that the average ecosystem service value in the Nenjiang River Basin decreased gradually from the northwestern upstream mountainous area to the southeastern downstream plain. The higher valuable area are located in the Da and Xiao Xing'anling Ranges, such as Mohe, Hulunbeier, and Heihe city, while the lower valuable area are Baicheng, Songyuan, and Suihua city in the downstream plain. However, the Xing'an League, which also belongs to the Da Xing'anling mountainous area, is of a lower average ecosystem service value due to four great grassland reclamation activities from the 1950s (Pan et al. 2002; Su et al. 2005). According to statistics, the area of farmland in the Xing'an League increased about $44.21 \%$ from 1996 to 2000 and $6.63 \%$ from 2001 to 2005 (Ying, 2009).

The average ecosystem service value all decreased from 1980 to 2005, except for Mohe and Tongliao city. The highest decline happened in Qiqihar city, from $25.96 \mathrm{USD} \cdot \mathrm{ha}^{-1}$ in 1980 to $24.13 \mathrm{USD} \cdot \mathrm{ha}^{-1}$ in 2005, decreasing about $1.82 \mathrm{USD} \cdot \mathrm{ha}^{-1} \cdot \mathrm{a}^{-1}$. Next were Heihe and Daqing city, where large-scale farms were built in the past.

\section{Discussion \\ Driving forces of land use/land cover and ecosystem service change}

The Nenjiang River Basin is an important foodstuff base and eco-environmental fragile area in Northeast China. Because temperature shows an increasing trend of $0.3{ }^{\circ} \mathrm{C}$ per decade in the recent 50 years in Northeastern China (Luan et al. 2007; Ju et al. 2007), exceeding the warming amplitude of global average temperature obviously (Liu, 2007), the $1{ }^{\circ} \mathrm{C}$ isotherm of average annual temperature gradually shifted northward during 1986-2000 (Wang et al. 2009); the growing season was so prolonged that rice could be cultivated in more northern areas than ever before. The previous wetland or grassland, even non-irrigated dry fields, was reclaimed as paddy field under encouragement policy, resulting in the dramatic decrease of grassland or wetland and increment of farmland.

However, annual and seasonal precipitation in Northeastern China shows slightly decreasing trends, especially in summer precipitation (Ren et al. 2000; Lu, 2009). In the Nenjiang River Basin, the warming and drying trend has influenced the seasonal streamflow and altered the annual hydrograph of the basin. The decrease of streamflow in the lower basin (mainly alluvial plains) has caused wetland degradation, desertification, and soil salinization (Zhang and Guo 2008; Du et al. 2009; Feng et al. 2011).

Land use and land cover changes are particularly related to the increase of population and intensive agriculture (Verburg et al. 1999). Due to the increase in population and the concomitant requirement of grain, the building of farmland not only accelerated deforestation and cultivation of grassland and wetland but also resulted in damages to the ecological environment such as land degradation and ecosystem service recession.

According to the study by Han et al. (2005) in Zhaoguang Farm, which was the first mechanical farm built in Heihe city in late 1950s, the vegetation has changed from natural vegetation to cropweed, to rotation of corn-soybean-wheat, or to rotation of corn-soybean. 


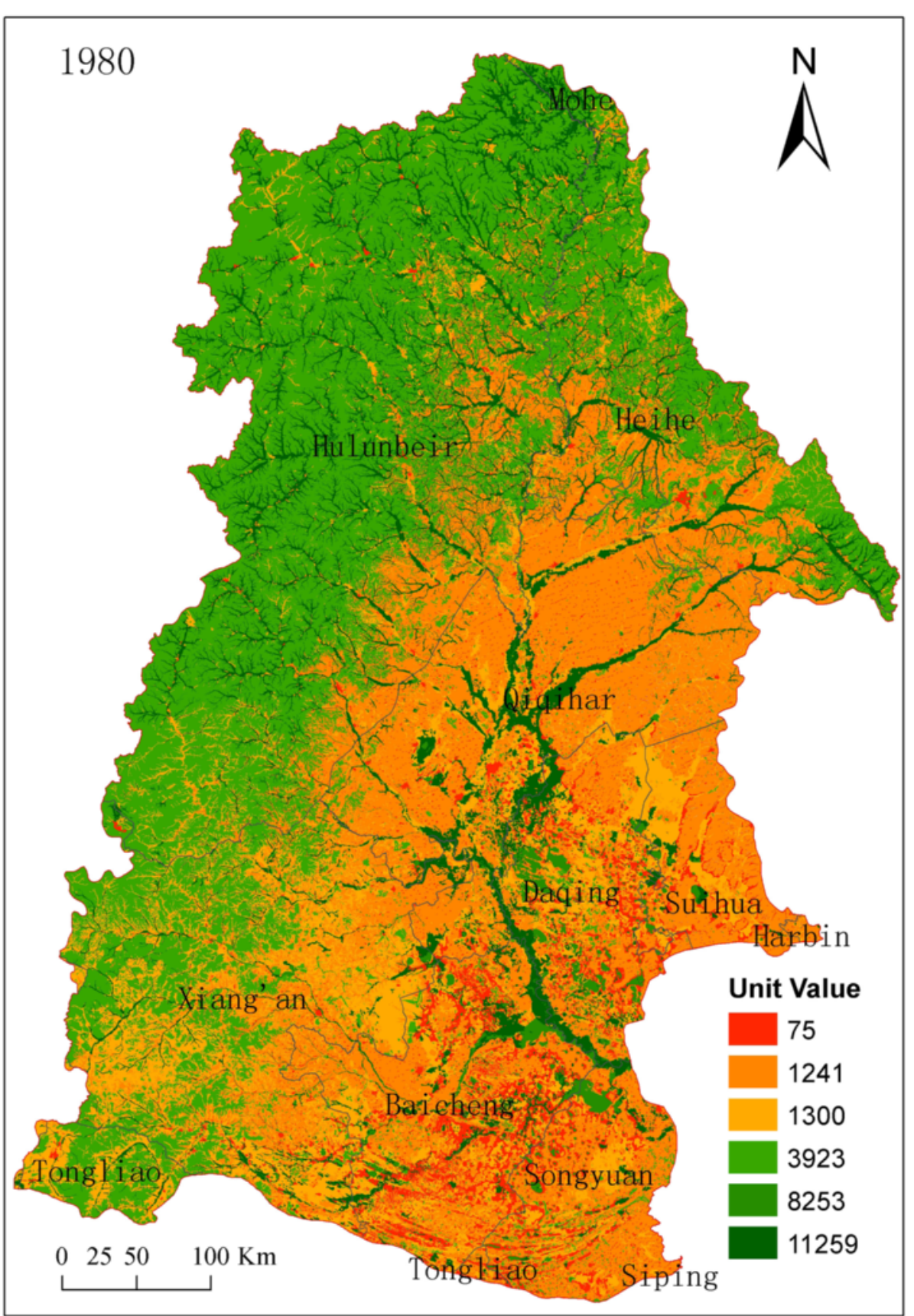

Fig. 3 Ecosystem service map of the Basin in 1980

The most important meadow soil has suffered substantial degradation after cultivation. If we took the soil $\mathrm{C}$ pool at the depth of $1 \mathrm{~m}$ in natural soil under the Steppified herbosa vegetation as control, the soil C pool under crops decreased by 7.76, 12.93, 14.66, $17.24,20.26$, and $23.71 \%$ after $2,8,15,30,50$, and 100 years cultivation, respectively (Fig. 5). Similarly, the soil $\mathrm{N}$ pool decreased by $6.5,9.6,11.3,12.4,12.5$, and $13 \%$, respectively, in contrast to the increased trend of the soil $\mathrm{N}$ pool in the 0 - to 50 -cm-deep natural meadow soil.

For the same weather condition, in contrast to water storage in the 1-m-deep natural meadow soil, the water storage of soil after cultivation would decrease from 20.40 to $29.30 \%$ in spring, 17.60 to $30.80 \%$ in summer, and 19.70 to $29.90 \%$ in Autumn (Fig. 6).

Deforestation and destruction of grassland has severely altered water distribution on land surface. 


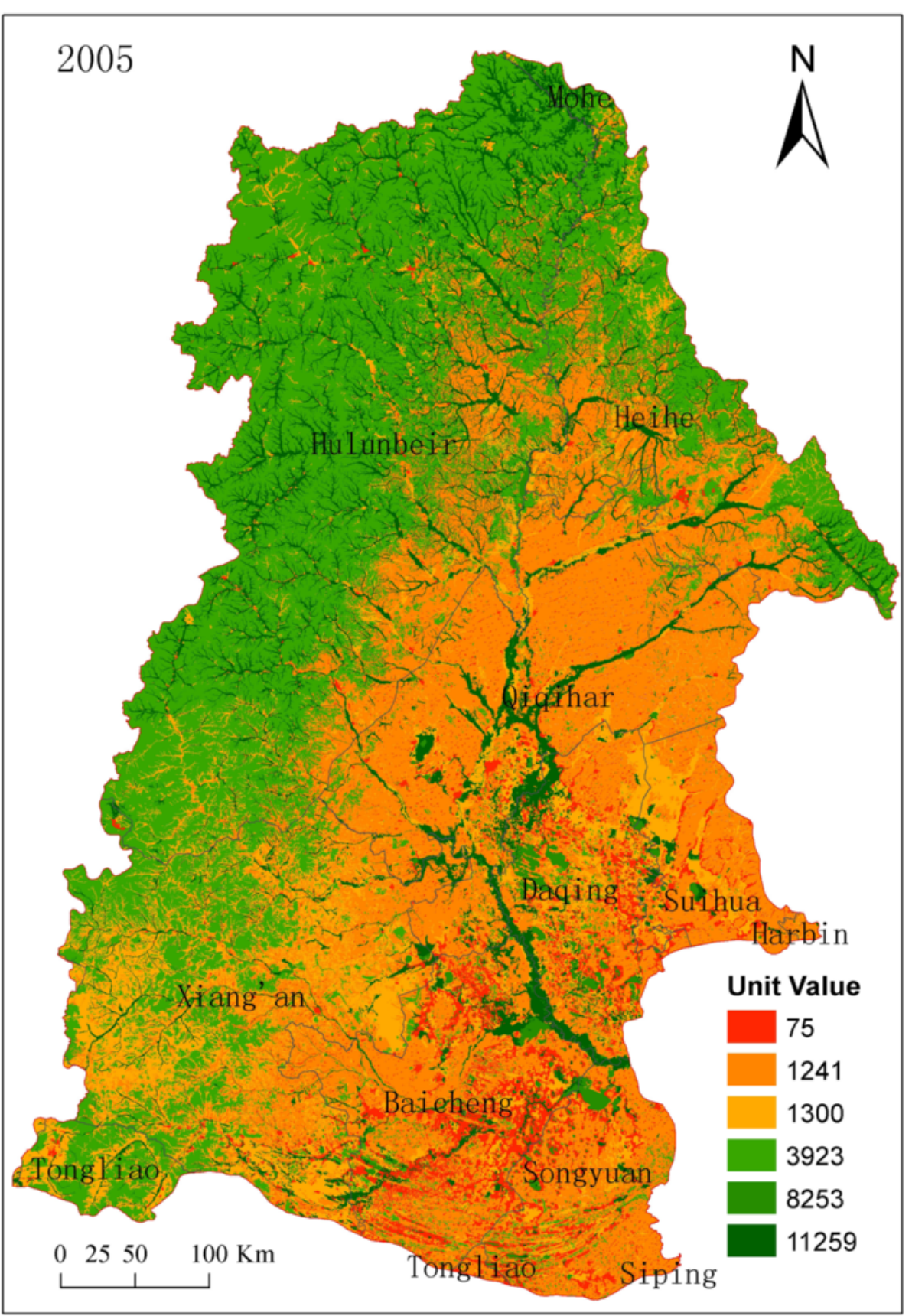

Fig. 4 Ecosystem service map of the Basin in 2005

Instead of infiltration and percolation, most of the surface runoff enters the channel directly during heavy rain, carrying soil from denuded farmland with it (Liu et al. 2005).

In short, it is land use/land cover changes that make tremendous influence on water and soil losses, but there is a little relationship of water and soil losses with the cultivation time. The effect of soil use/cover is bigger than the time effect (Han et al. 2005).

\section{The effect of policy}

Similar to the rest of China, policies of the central government put direct and important effects on land use/land cover changes in the Nenjiang River Basin. In the early 1980s, the decentralized decision-making in agricultural production of the household contract responsibility system afforded farmers more freedom in looking after their own interest. But, the central government attached great importance to food self- 
Table 9 Total area and economic value of each city from 1980 to 2005 (USD $\cdot \mathrm{ha}^{-1} \cdot \mathrm{a}^{-1}$ )

\begin{tabular}{|c|c|c|c|c|c|c|c|c|}
\hline City $^{a}$ & Area (ha) & 1980 & Rank & 2005 & Rank & Change & Rank & Trend \\
\hline Mohe & 150,119 & 58.85 & 1 & 59.54 & 1 & 0.68 & 7 & $\uparrow$ \\
\hline Hulunbeier & $10,017,875$ & 45.84 & 2 & 45.78 & 2 & -0.06 & 10 & $\downarrow$ \\
\hline Heihe & $3,228,976$ & 38.74 & 3 & 37.07 & 3 & -1.67 & 2 & $\downarrow$ \\
\hline Tongliao & 565,079 & 30.71 & 4 & 30.96 & 4 & 0.25 & 8 & $\uparrow$ \\
\hline Daqing & $1,705,401$ & 30.28 & 5 & 28.73 & 5 & -1.55 & 3 & $\downarrow$ \\
\hline Xiang'an & $4,396,439$ & 27.53 & 6 & 26.75 & 6 & -0.77 & 6 & $\downarrow$ \\
\hline Qiqihar & $4,134,101$ & 25.96 & 7 & 24.13 & 7 & -1.82 & 1 & $\downarrow$ \\
\hline Baicheng & $2,453,927$ & 23.14 & 8 & 22.12 & 8 & -1.02 & 5 & $\downarrow$ \\
\hline Songyuan & $1,387,153$ & 18.70 & 9 & 17.23 & 9 & -1.47 & 4 & $\downarrow$ \\
\hline Suihua & $1,026,414$ & 16.40 & 10 & 16.22 & 10 & -0.18 & 9 & $\downarrow$ \\
\hline
\end{tabular}

${ }^{a}$ Cities of small area belonging to the Nenjiang River Basin were not included, such as Siping, Changchun, and Harbin

sufficiency; as users of the land (but not its owners), farmers still had to honor grain production quotas imposed by the government (Wang et al. 2009). Due to the inconsistency between decision-making at the macro-level and the objective of agricultural production at the micro-level, cultivated land was increased through zealous reclamation of grassland, marginal woodland, and even fallow land (Liu et al. 2005).

By the late 1990s, after market-oriented reforms introduced to the agrarian sector, northeast-grown maize and soybean were not as profitable as rice in the market. Thus, large-scale farms were transformed into paddy fields; such changes have caused a severe shortage of water resources and the shrinkage of lakes/rivers along with climate change. These years, although the ecological functions of woodland, grassland, and wetlands were recognized widely and ecological projects such as "Grain for Green" and "Construction of Ecological Province" were adopted, driven by the shortterm economic interests, in the less developed county, the reclamation of reserve resources still caused a

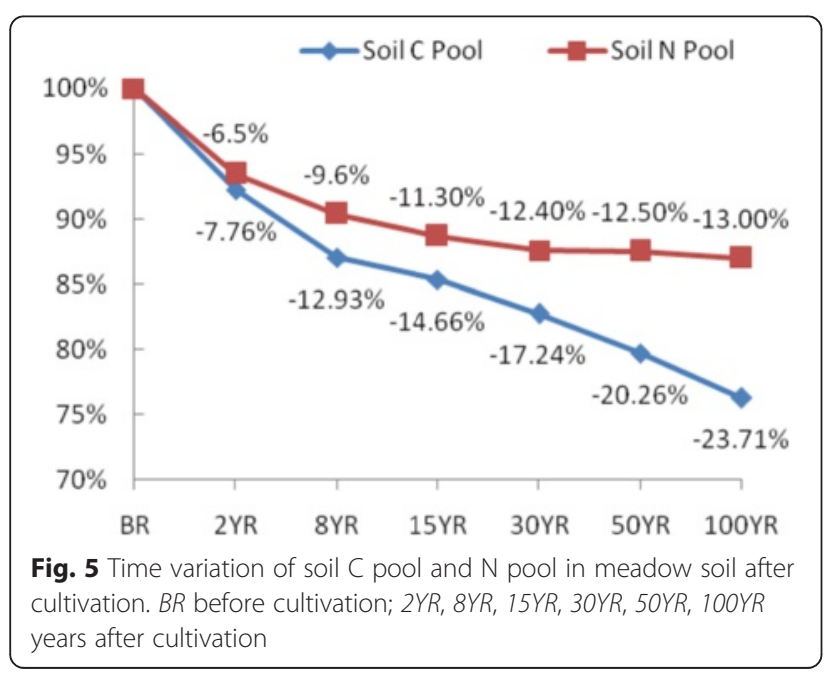

substantial increase of farmland, and the amount of agricultural labor grew steadily (Liu and Li 2010).

\section{Conclusions}

According to the above calculation and analysis, in the Nenjiang River Basin, the two most valuable land use types were forest ( 40.00 billion USD, about $40.03 \%$ of the total value in 1980; 38.71 billion USD, about $39.70 \%$ of the total value in 2005) and wetland (38.14 billion USD, about $38.16 \%$ of the total value in 1980; 37.90 billion USD, about $37.90 \%$ of the total value in 2005), which are mainly located in the upstream Da and Xiao Xing'anling mountainous area, such as Mohe, Hulunbeier, and Heihe city. The economic value of land use types decreased obviously from 1980 to 2005, especially in the grassland of the downstream plain, such as Qiqihar and Daqing city, where large-scale grassland and wetland were reclaimed as farms in the past.

As for individual ecosystem service, besides the food production, all of the ecosystem service values declined from 1980 to 2005, of which water regulation and supply decreased the most for the human-induced cultivation and the warming and drying trend in the Nenjiang River Basin.

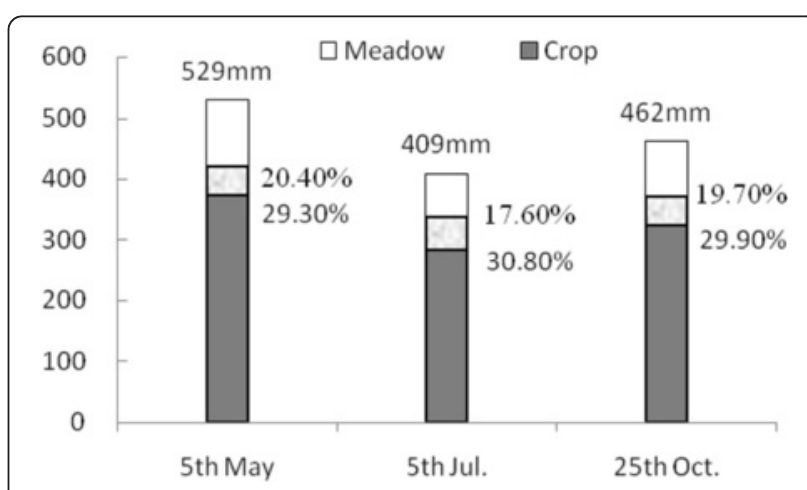

Fig. 6 Time variation of water storage in 1-m-deep meadow soil after cultivation 
In a word, the economic value of ecosystem services in the Nenjiang River Basin decreased 2.43 billion USD, about 97.2 million USD per year from 1980 to 2005, due to tremendous land use/land cover changes under the encouragement policy during the past decade. So, the policies of Grain for Green and Construction of Ecological Province projects should be well-implemented to optimize land use/land cover.

\section{Competing interests}

The authors declare that they have no competing interests.

\section{Authors' contributions}

$Z L W, Z W$, and BZ designed the research; ZLW, CL, and $C R$ conducted the research and analyzed the data; ZLW drafted the manuscript; ZW, BZ, and CR revised the manuscript. All authors read and approved the final manuscript.

\section{Author details}

${ }^{1}$ Northeast institute of Geography and Agroecology, Chinese Academy of Sciences, Changchun 130102, China. ${ }^{2}$ University of Chinese Academy of Sciences, Beijing 100101, China. ${ }^{3}$ ScienceCollege of Qiqihar University, Qiqihar 161006, China.

\section{Received: 16 December 2014 Accepted: 7 June 2015}

\section{Published online: 30 June 2015}

\section{References}

Anna H, Sabine S, Thomas W (2011) The concept of ecosystem services regarding landscape research: a review. Living Rev Landscape Res 5(1):5-25

Bai $Y$, Ouyang $Z Y$, Zheng $H, X u$ WH, Jiang P, Fang $Y$ (2011) Evaluation of the forest ecosystem services in Haihe River Basin, China. Acta Ecol Sin 31(07):2029-2039

Boone RB, Galvin KA (2000) Generalizing El Nino effects upon Maasai livestock using hierarchical clusters of vegetation patterns. Photogramm Eng Remote Sens 66(6):737-744

Costanza R, dArge R, de Groot R, Farber S, Grasso M, Hannon B, Limburg K, Naeem S, Oneill RV, Paruelo J, Raskin RG, Sutton P, van den Belt M (1997) The value of the world's ecosystem services and natural capital. Nature $387: 253-260$

Dong LQ (2013) Effects of climate change on wetland hydrology and water resources and the adaptation strategies in Nenjiang River Basin. University of Chinese Academy of Sciences, Beijing (China)

Du SM, Gong WF, Du C, Du CX (2009) Spatiotemporal change of desertification in lower reaches of Nenjiang River: a remote sensing analysis based on MODIS data. J Nat Disasters 18(5):131-137

Feng XQ, Zhang GX, Yin XR (2011) Hydrological responses to climate change in Nenjiang River Basin, Northeastern China. Water Resour Manag 25(2):677-689

Freitas SR, Mello C (2005) Relationships between forest structure and vegetation indices in Atlantic Rainforest. For Ecol Manag 218(1):353-362

Han XZ, Wang SY, Song CY, Qiao YF (2005) Effects of land use and cover change on ecological environment in black soil region. Sci Geol Sin 25(2):203-207

Hou W, Wang Y, Ma XP, Wu D, Xu CB, Hu C, Li X (2013) Changes of temporalspatial pattern and services evaluation of the ecosystem in the Liaohe river basin. J Meteorology Envi 29(4):71-76

Hu RF, Leng Y (2006) A study on input and output of main grain crops in China. J Agrotechnical Econ 3:2-81

Huete A, Didan K, Miura T, Rodriguez EP, Gao X, Ferreira LG (2002) Overview of the radiometric and biophysical performance of the MODIS vegetation indices. Remote Sens. Environ. 83:195-213

Ju H, Xiong W, Xu YL, Lin ED (2007) Climate change and its impacts in Northeast China. Chin AgricSci Bull 23(4):345-349

Kerr MF, Ostrovsky M (2003) From space to species: ecological applications for remote sensing. Trends Ecol Evol 18(6):299-305

Li HY, Wang XY, Jia LN, Wu YN, Xie M (2014) Runoff characteristics of the Nen River Basin and its cause. J Mt Sci 11(1):110-118

Liu CM (2007) Study on water and eco-environmental problems and protection strategy. Science Press, Beijing
Liu YS, Li YR (2010) Spatio-temporal coupling relationship between farmland and agricultural labor changes at county level in China. Acta Geograph Sin 65(12):1602-1612

Liu YS, Gan H, Gao J, Deng XS (2004) The causes and environmental effects of land use conversion during agricultural restructuring in Northeast China. J Geogr Sci 14(4):488-494

Liu YS, Wang D, Gao J, Deng W (2005) Land use/cover changes, the environment and water resources in Northeast China. Environ Manag 36(5):691-701

Liu MC, Li DQ, Wen YM, Luan XF (2006) Function and value of water-holding in Sanjiangyuan region. Res Envi Yangtze Basin 15(3):405-408

Liu JW, Jin TT, Liu GH, Li ZS, Yang RJ (2014) Changes in land use and soil and water conservation of the upper and middle reaches of Heihe river basin during 2000-2010. Acta Geograph Sin. doi:10.5846/stxb201303010328

Loris V, Damiano G (2006) Mapping the green herbage ratio of grasslands using both aerial and satellite-derived spectral reflectance agriculture. Ecosys Envi 115:141-149

Lu AG (2009) Spatial precipitation variation across China during 1951-2002. Ecol Environ Sci 18(1):46-50

Luan ZQ, Zhang GX, Deng W, Hu JM, Zhou DM (2007) Studies on changes of air temperature and precipitation for last 50 years in Songnen Plain. Chin J Agrometeorol 28(4):355-358

Pan JW, Zhong HP, Yun XJ (2002) Natural grassland reclamation and its ecological impaction in recent 50 years. Grassland of China 24(5):69-72

Ren GY, Wu H, Chen ZH (2000) Spatial patterns of change trend in rainfall of China. Q J Appl Meteorol 11(3):322-330

Roces-Díaz JV, Díaz-Varela RA, Álvarez-Álvarez P, Recondo C, Díaz-Varela ER (2014) A multiscale analysis of ecosystem services supply in the NW Iberian Peninsula from a functional perspective. Ecol Indic 50:24-34

Running SW, Baldocchi DD, Turner DP, Gower ST, Bakwin PS, Hibbard KA (1999) A global terrestrial monitoring network integrating tower fluxes, flask sampling, ecosystem modeling and EOS satellite data. Remote Sens Environ 70(1):108-127

Stoms DM, Hargrove WW (2000) Potential NDVI as a baseline for monitoring ecosystem functioning. Int J Remote Sens 21:401-407

Su H, Liu GX, He T (2005) Reclamation of grassland and its harm. Grassland China 27(6):61-63

Sun YG, Bai RH (2005) Main meteorological disaster in Songhua river and Nen river. Meteorological Press, Beijing

Verburg PH, Veldkamp A, Bouma J (1999) Land-use change under conditions of high population pressure: the case of Java. Glob Environ Change 9(4):303-312

Wang ZM, Zhang B, Zhang SQ, Li XY, Liu DW, Song KS, Li JP, Li F, Duan HT (2006) Changes of land use and of ecosystem service values in Sanjiang plain, Northeast China. Environ Monit Assess. doi:10.1007/s10661-006-0312-5

Wang ZM, Liu ZM, Song KS, Zhang B, Zhang SM, Liu DW, Ren CY, Yang F (2009) Land use changes in Northeast China driven by human activities and climatic variation. Chin Geogra Sci 19(3):225-230

Wu X, Shen ZY, Liu RM, Gong YW (2009) Effects of land use change on ecosystem services value of the upper reaches of the Yangtze River. Transact CSAE 25(8):236-241

Xie GD, Lu CX, Leng YF, Zheng D, Li SC (2003) Ecological assets valuation of the Tibetan Plateau. J Nat Res 18(2):189-196

Xie GD, Xiao Y, Zhen L, Lu CX (2005) Study on ecosystem services value of food production in China. Chinese J Eco-Agri 13(3):10-13

Xie GD, Zhen L, Lu CX, Xiao Y, Chen C (2008) Expert knowledge based valuation method of ecosystem services in China. J Nat Res 23(5):911-919

Ying G (2009) Negative effect of cultivation in Xiang-an League since foundation of the country. Inner Mongolia normal university, Huhehot

Zhang GX, Guo YD (2008) Study on the wetland ecological and hydrological functions and their degradation mechanisms and counter measures in the middle and lower reaches of Nenjiang River. J Arid Land Resour Environ 22(1):122-128

Zhang WG, Hu YM, Zhang J, Liu M, Yang ZP (2007) Assessment of land use change and potential eco-service value in the upper reaches of Minjiang River, China. J For Res 18(2):97-102

Zhang YR, Zhou DM, Niu ZG, Xu FJ (2013) Valuation of lake and marsh wetlands ecosystem services in China. Chin Geogra Sci doi:. doi:10.1007/s11769-013-0648-z 